\title{
Dawne kolejowe rozkłady jazdy i ich przydatność w badaniach historycznych*
}

Zarys treści: Artykuł poświęcony jest kolejowym rozkładom jazdy wydanym na ziemiach polskich w okresie XIX i pierwszej połowie XX w. W pierwszej części tekstu ogólnie charakteryzuję źródło (stan jego zachowania, typy rozkładów, przemiany ich formy, częstotliwość wydań, nakład, wydawców, cenę). W dalszej części tekstu, wskazuję przydatność rozkładów jazdy w badaniach historycznych, kładąc nacisk na ich wykorzystanie w szeroko pojmowanych pracach z zakresu historii podróżowania, kolejnictwa, turystyki oraz historii społecznej i gospodarczej.

Abstract: The article deals with railway timetables published in Polish lands during the nineteenth century and the first half of the twentieth century. The first part of the text is a general characteristic of the source (the state of its preservation, types of schedules, transformations of their forms, editions, publisher, and price). A further part of the article indicates the expediency of railway timetables in historical research, with emphasis placed on their use in widely comprehended studies on the history of travelling and the rail industry, as well as social and economic history.

Słowa kluczowe: kolejowe rozkłady jazdy 19-20 w., przewozy pasażerskie, organizacja transportu kolejowego w Polsce 19-20 w., informacja na kolei.

Keywords: railroads schedule $19^{\text {th }} / 20^{\text {th }}$ century, passenger transports, organization of transports by rail in Poland of the $19^{\text {th }} / 20^{\text {th }}$ century, information on the railway.

Rozwój kolejnictwa na ziemiach polskich w XIX i pierwszej połowie XX wieku, charakteryzujący się mnogością nowych szlaków, dynamiczną rozbudową infrastruktury, czy rozkwitem myśli technicznej, zaowocował także masowymi edycjami źródeł drukowanych przeznaczonych dla podróżnych i obsługi (obwieszczenia, instrukcje, bilety, foldery czy rozkłady jazdy). W odróżnieniu od badaczy zachodnioeuropejskich, którzy tym źródłom poświęcili szereg wartościowych prac, w tym odrębne monografie ${ }^{1}$, w rodzimej historiografii brak prac całościowo ujmujących analizowany problem. Kilka przyczynkarskich opracowań poświęconych samym rozkładom jazdy i fragmenty prac udanie wykorzystujących te źródło w badaniach historycznych ${ }^{2}$, w oczywisty sposób nie ukazują jego

\footnotetext{
* Pragnę w tym miejscu serdecznie podziękować Panu dr. Dawidowi Kellerowi za okazaną pomoc podczas pisania niniejszego artykułu.

${ }^{1}$ M.I. Bray, Railway Tickets, Timetables \& Handbills, Ashbourne 1986; B.S. Lomazzi, Railroad Timetables, Travel Brochures and Poster. A History and Guide for Collectors, Golden Hill 1995; V. Bradshaw-Mitchell, Bradshaw's History, Midhurst 2012; M.O. Esbester, Designing time: the design and use of nineteenth-century transport timetables, „Journal of Design History" 22, 2009, no 2, p. 91-113.

${ }^{2}$ Zob. m.in. fragmenty monografii: P. Dominas, Powstanie i rozwój kolei na Ziemi Kłodzkiej w latach 1854-1914, Kłodzko 2009; D. Keller, Dyrekcja Okręgowa Kolei Państwowych w Katowicach w latach 1922-1939: geneza, podstawy prawne,
} 
wszystkich walorów, ani też nie odpowiadają na liczne pytania i wątpliwości. Wciąż brak pogłębionej refleksji nad znaczeniem i przydatnością owych materiałów w badaniach historycznych. Lakoniczne wzmianki, które na ten temat przy różnych okazjach się pojawiają, problematyki nie wyczerpują, dają jedynie asumpt do rozwinięcia tematu.

Artykuł poświęcam pasażerskim rozkładom jazdy, wydanym w postaci odrębnych druków, które trafiły do obiegu na przestrzeni XIX i pierwszej połowy XX wieku, ściślej zaś do 1939 r. Z rozważań wyłączyłem rozkłady przeznaczone do użytku służbowego. Uczyniłem tak, z uwagi na brak reprezentatywnej liczby pozycji, które mógłbym poddać analizie. Kilka tytułów, na które natrafiłem w trakcie kwerendy bibliotecznej nie uprawnia do formułowania uogólnień. Warto jednakże w tym miejscu odnotować, że owych rozkładów używano w normalnych warunkach przewozowych oraz w czasie nadzwyczajnym, np. na wypadek ogłoszenia stanu wojny³. Do druków służbowych należałoby także zaliczyć rozkłady wojskowe, które z całą pewnością wydawano w okresie międzywojennym.

$Z$ rozważań wykluczyłem także rozkłady zamieszczane w innych masowych drukach. Pozycje tego typu prezentują zwykle mniejszą wartość informacyjną, jednocześnie zaś, potwierdzają wnioski płynące z lektury rozkładów wydanych, jako druki samodzielne. Dla pewnego jednak porządku warto dopowiedzieć, że do czasu wybuchu pierwszej wojny światowej rozkłady pasażerskie regularnie publikowano w lokalnej prasie, a także np. w kalendarzach i przewodnikach turystycznych, wydawanych w tysiącach, czy dziesiątkach tysięcy egzemplarzy. Fakt ten dowodzi, dużego ówczesnego zapotrzebowania społecznego na tego typu informacje. Stała obecność rozkładów jazdy w drukach masowych, aż po 1914 r., może także świadczyć o tym, że standardowe rozwiązania informacyjne podejmowane przez kolej $\mathrm{w}$ tym czasie były niewystarczające. Zmianę przyniosło odrodzenie się państwa polskiego. Upaństwowienie kolei w II RP skutkowało tym, że za politykę informacyjną odpowiadała głównie sama kolej i jej różne agendy, w mniejszym zaś stopniu redakcje gazet, czy wydawcy druków masowych.

Stan zachowania kolejowych rozkładów jazdy jest zły, co przypisać należy samej specyfice źródła. Druki o ograniczonym terminie ważności, a do takich rozkłady jazdy zaliczyć wypada, nigdy nie budziły, co jest w pewien sposób zrozumiałe, większego zainteresowania bibliotek powszechnych, nastawionych na kompletowanie pozycji innego typu. Traktowano je zwyczajnie, jako druki podrzędnej kategorii. Rozkłady były (i wciąż są) rzadkością w domowych bibliotekach. Ich przydatność dla domowników kończyła się najczęściej z chwilą wydania nowego rozkładu jazdy, co w ciągu roku regularnie miało miejsce. Trwałość źródła obniża także papier użyty w druku, często niskiej jakości, oraz brak sztywnych, mocnych okładek, do dzisiaj często nie zachowanych, co komplikuje przeprowadzenie opisu bibliograficznego i krytykę naukową. Kolejowe rozkłady jazdy należą, więc do druków rzadkich, największe krajowe biblioteki, w tym także te specjalistyczne, posiadają skromne, niepełne zbiory ${ }^{4}$, co komplikuje, niekiedy wręcz uniemożliwia, prowadzenie analizy porównawczej. Pozycje trafiające do obiegu antykwarycznego są rzadkością, osiągając na aukcjach niekiedy pokaźne ceny.

organizacja i funkcjonowanie, Rybnik 2013 oraz D. Opaliński, Dyszlem i pod para, czyli o galicyjskim kolejowo-pocztowym rozkładzie jazdy z 1867 r., Kwart. HKM, 2014 nr 4, s. 613-624; tenże, Kolejowe rozkłady jazdy w okresie II RP — funkcje społeczne źródła, w: Komunikowanie i komunikacja w dwudziestoleciu międzywojennym, red. K. Stępnik i M. Rajewski, Lublin 2010, s. 325-335; a także krótki szkic analizujący kulturową rolę rozkładów Thomasa Cooka, zob. W. Tomasik, To już jest koniec... w: tenże, Pociag do nowoczesności. Szkice kolejowe, Warszawa 2014, s. 275-280.

${ }^{3}$ Rozkład jazdy dla slużby dróg żelaznych warszawsko-wiedeńskiej i warszawsko-bydgoskiej wprowadzony od dnia 15 maja 1872, Warszawa 1872; Rozkład jazdy dla służby dróg żelaznych warszawsko-wiedeńskiej i warszawsko-bydgoskiej wprowadzony od dnia 1 listopada 1872 roku, Warszawa 1872; Rozkład jazdy dla służby dróg żelaznych warszawsko-wiedeńskiej i warszawsko-bydgoskiej wprowadzony od dnia 1(13) maja 1875 roku, Warszawa 1875; Rozkład jazdy dla stużby dróg żelaznych warszawsko-wiedeńskiej i warszawsko-bydgoskiej wprowadzony od dnia 3 (15) maja 1879 roku, Warszawa 1879; Rozkład jazdy na czas wojenny dla służby dróg żelaznych warszawsko-wiedeńskiej i warszawsko-bydgoskiej od 1 (13) listopada 1882 roku, Warszawa 1883.

4 Wyjątkiem jest Biblioteka Narodowa w Warszawie, w której zasobie znajduje się pokaźna liczba rozkładów jazdy, głównie z okresu międzywojennego, nadsyłanych z różnych stron kraju przez ówczesnych starostów. 
Dokładna inwentaryzacja wszystkich rozkładów jazdy wydanych drukiem na ziemiach polskich w okresie zaborów i II RP jest zadaniem obecnie niewykonalnym. Podstawową przeszkodą jest brak pewnych danych o edycjach samych rozkładów, ich nakładzie i podmiotach wydawniczych. Powszechnie wykorzystywane przez historyków bibliografie są niekompletne trudno, zatem na ich podstawie, odtworzyć pełny spis kolejowych rozkładów jazdy ${ }^{5}$. Wszystko to sprawia, że na etapie heurezy historycy są zdani głównie na katalogi biblioteczne. Kwerendą objąłem kilkadziesiąt pozycji pochodzących ze zbiorów bibliotek: Narodowej, Jagiellońskiej, Ossolineum, Muzeum Kolejnictwa w Warszawie, Muzeum Narodowego Ziemi Przemyskiej w Przemyślu oraz Głównej Biblioteki Komunikacyjnej w Warszawie. Przydatność w tym względzie archiwów okazała się znikoma. Dla przykładu w zespole galicyjskich akt k.k. Eisenbahnministerium (Archiwum Główne Akt Dawnych w Warszawie) znajduje się jeden rozkład z 1903 r..

Przez pierwszych kilka dziesięcioleci istnienia kolei na ziemiach polskich wydawano rozkłady zazwyczaj nieregularnie, na dodatek w zasadzie każde z towarzystw kolejowych prowadziło odrębną politykę informacyjną. Rzadko w tym czasie ukazywały się zbiorcze rozkłady jazdy, wspólne dla więcej niż jednego towarzystwa i obejmujące większy fragment w obrębie zaboru? . W kolejnych dziesięcioleciach coraz częściej dochodziło do śmielszych przedsięwzięć wydawniczych, inspirowanych i koordynowanych zazwyczaj przez państwowych przewoźników ${ }^{8}$. Zdarzało się także, że inicjatywy te wykraczały poza zabór, nie wychodząc jednakże poza granice ówczesnych państw, np. rozkłady kolejowe dla Galicji zestawiano z rozkładami Bukowiny ${ }^{9}$, czy z pozostałymi częściami

\footnotetext{
${ }^{5}$ Pomoc często wykorzystywana przez historyków XIX w. w poszukiwaniach bibliograficznych, bibliografia Karola Estreichera, dostarcza nam fragmentarycznych i nie do końca pewnych danych w tej kwestii. We wszystkich zasadniczych tomach starej i nowej edycji oraz uzupełnieniach odnoszących się do XIX stulecia, odnajdujemy zaledwie około czterdziestu pozycji, które należałoby objąć poniższą refleksją. Na dodatek odnoszą się one niemal wyłącznie do obszarów Królestwa Polskiego i Galicji. Widoczny jest niedobór rozkładów obejmujących Poznańskie. W przypadku Galicji i Królestwa Estreicher wymienia głównie druki polskojęzyczne, a pomija szereg rozkładów w języku niemieckim i rosyjskim. Niemal zupełnie rzeczona bibliografia nie odnotowuje służbowych rozkładów jazdy. Jeśli, zaś idzie o okres międzywojnia, to brak pomocy bibliograficznej przydatnej w kwerendzie rozkładów jazdy — na wzór Estreichera — jest jeszcze bardziej dotkliwy. Periodyki „Książka” i „Nowa Książka” rzadko, kiedy podają pełne i pewne dane; ostatni zaś z tomów, 17., Bibliografii Polski 1901-1939, wydany w 2015 r., doprowadzono do haseł na literę K. Hasło kluczowe dla analizowanego tu problemu „rozkład”, wciąż czeka na gruntowne opracowanie. Wymienione pomoce, szczególnie te wydane po 1900 r., w interesujących nas poszukiwaniach pełnią raczej rolę drugorzędną. Wszystkie wymienione dotąd pozycje nie rejestrowały zwykle rozkładów ściennych oraz wydawnictw broszurowych, które w okresie międzywojnia drukowano już masowo dla poszczególnych stacji węzłowych i przelotowych.

${ }^{6}$ Por. J. Bugajski, „Galicyjskie” akta c.k. Ministerstwa Kolei i ich opracowanie, „Archeion” 60, 1974, s. 177-193. Niezadowalające efekty przyniosło także przeszukiwanie elektronicznych baz danych opracowanych przez archiwa państwowe, por: $<$ http://szukajwarchiwach.pl/search?q=rozk\%C5\%82ady\%20jazdy> [dostęp: 09.11.2015].

7 Przykładem takich inicjatyw były: Dokładny rozkład jazdy kolei galicyjskich, Lwów 1876; Rozkład i ceny jazdy droga żelazna z Krakowa do Lwowa, Czerniowiec, Wrocławia, Poznania i Wiednia. Przepisy pocztowe tudzież wykaz poczt osobowych w Galicji i opłaty od depesz telegraficznych, Kraków 1867.

${ }^{8}$ Rozklad jazdy dla szlaków: I. Zwardoń - Husiatyń, II. Oświęcim - Podgórze, III. Sucha - Skawina, IV. Grybów - Tarnów, V. Nowy Sacz - Orłów, VI. Zagórzany - Gorlice, VII. Drohobycz - Borysław, VIII. Stryj - Lwów. Ważny od 1 czerwca 1885 roku, [Kraków 1885]; Fahrordnung für die Strecken: I. Zwardoń - Husiatyń, II. Oświęcim - Podgórze, III. Sucha - Skawina, IV. Grybów - Tarnów, V. N[eu] Sandez - Orlo, VI. Zagórzany - Gorlice, VII. Drohobycz - Borystaw, VIII. Stryj - Lemberg. Giltig vom 1. October 1885, [Krakau 1885]; Rozkład jazdy dla szlaków: I. Zwardoń - Husiatyń, II. Oświęcim - Podgórze, III. Sucha - Skawina, IV. Grybów - Tarnów, V. Nowy Sacz - Orłów, VI. Zagórzany - Gorlice, VII. Drohobycz - Borysław, VIII. Stryj - Lwów. Ważny od 1 czerwca 1886 r., [Kraków 1886].

${ }^{9}$ Kurier Kolejowy. Ważny od 1. maja 1914. Rozkład jazdy pociagów osobowych i pospiesznych w Galicji i Bukowinie. Połaczenia do miast za granica, do miejsc kapielowych oraz ceny biletów do wszystkich stacji. Eisenbahn-Courier. Giltig vom 1. Mai 1914. Fahrplan der personen- und eilzüge für Galizien und Bukowina. Samt Verbindungen mit den Städten des Auslandes, der Curorte, und Fahrkartenpreise für alle Stationen, Lwów 1914; Konduktor. Rozkład jazdy na szlakach kolejowych Galicji i Bukowiny z dodatkiem najwięcej uczęszczanych krajowych i zagranicznych relacji. Wazny od 1 maja 1913. R. 2, Lwów [1913]; Galicyjski rozkład jazdy sprawdzony odnośnie do szlaków c.k. Kolei Państw[owych] w Galicyi i Bukowinie przez Dyrekcyę Kolei Państwowych. Kompletne wydanie dla Galicyi, Śląska Ciesz[yńskiego] i Bukowiny, z cenami biletów, 1914 sezon letni, czerwiec-sierpień, R. III, wyd. 21, Lwów 1914.
} 
monarchii ${ }^{10}$. Z analogiczną sytuacją mieliśmy do czynienia w Królestwie Polskim, gdzie rozkłady miejscowe łączono z rozkładami kolei Cesarstwa Rosyjskiego ${ }^{11}$. Projekty międzyzaborowe na szerszą skalę nie zyskiwały aprobaty dyrekcji kolejowych i wydawców. Wszelkie działania podkreślające integralność ziem polskich (a takimi byłyby z pewnością edycje zawierające ponadzaborowe połączenia), budziły nieufność instytucji stojących na straży istniejącego porządku ${ }^{12}$. Ograniczano się, zatem do wydawania swoistych namiastek rozkładów ponadzaborowych, zawierających tylko wybrane połączenia, zazwyczaj w ruchu transgranicznym. Daje się natomiast zaobserwować wyraźny wzrost zainteresowania ruchem pociągów zagranicznych kolei. Świadczą o tym pojawiające się w rozkładach informacje ułatwiające dojazd do europejskich metropolii i popularnych kurortów. Zainteresowanie wspomnianą tematyką wynikało z generalnej zmiany nawyków podróżnych na przełomie XIX i XX wieku. Transgraniczne wojaże stały się — już wówczas — czymś naturalnym podobnie, jak potrzeba szybkiej i podręcznej informacji dostępnej w podróży. Pewną odmianą rozkładów zbiorczych były pozycje zawierające porządek jazdy wybranych typów pociągów. Za przykład mogą posłużyć wydawnictwa z rozkładami jazdy składów prowadzących wagony sypialne i restauracyjne ${ }^{13}$. Do rzadkości w okresie zaborów należały edycje rozkładów dla poszczególnych stacji i węzłów kolejowych, nawet tych o kluczowym znaczeniu, co dowodzi nikłego jeszcze wówczas zapotrzebowania na podobne druki ${ }^{14}$.

Oprócz wersji książkowej, rozkłady jazdy przybierały formę składanych kieszonkowych folderów, kartoników (tzw. rozkłady portfelowe), czy wielkoformatowych afiszy, umieszczanych w miejscach publicznych.

Nie ma pewności, czy przez cały okres objęty badaniami stosowano okresowe zmiany rozkładów jazdy. Brak jednoznacznej wzmianki o czasie obowiązywania niektórych pozycji, każe domniemywać, że nie zawsze do takowej zmiany dochodziło, lub też, że wprowadzone poprawki miały charakter kosmetyczny, a tym samym nie zachodziła konieczność przygotowania nowego druku. Nie wydaje się, zatem by w pierwszym ćwierćwieczu istnienia kolei na ziemiach polskich korekty rozkładów jazdy były zabiegiem powszechnym i systematycznym. Wydawano, więc w owym czasie pozycje, które noszą oznaki okresowości ${ }^{15}$, jak też i druki, które takowych znamion nie posiadają ${ }^{16}$. Zmiany rozkładów jazdy w kolejnych dekadach XIX i w początkach XX wieku następowały już dość regularnie, co poświadczają stosowne adnotacje umieszczane na kartach tytułowych oraz wewnątrz omawianych druków. W tym czasie utrwalił się podział na zasadniczo dwa sezony przewozowe, letni i zimowy. Wraz z ich początkiem w maju/czerwcu oraz październiku/listopadzie do-

\footnotetext{
${ }_{10}$ Österreichisches kursbuch offizielle ausgabe. Fahrpläne der österreichisches, ungarischen und bosnisch-hercegovinischen eisenbahnen und dampfschiffe, Wien 1907.

${ }^{11}$ B. Pietrzykowski, Nowy przewodnik na kolejach żelaznych w Królestwie Polskim i przylegających. Rok I, Warszawa 1899-1900; Expresse. Przewodnik kolejowy i handlowy, red. W. Rakowskiego. Opracowany na podstawie źródet ściśle urzędowych, wyd. 12, 1901, Warszawa 1901; wyd. 16, 1904, Warszawa 1904.

12 Por. J. Kostecki, M. Rowicka, Dozwoleno z iskluczenjem. Ingerencje rosyjskiej cenzury zagranicznej w latach 1869-1900, w: Piśmiennictwo - systemy kontroli - obiegi alternatywne, red. J. Kostecki, A. Brodzka, t. 1, Warszawa 1992, s. $272-275$.

${ }^{13}$ K. K. Oesterr[eichische] Staatsbahnen. Directe Zugverbindungen mit Angabe der Fahrpreise, des Verkehres von Schlafwagen und Restaurationswagen für nachstehende Routen: Wien via Arlberg - Paris; Wien - Salzburg - Süddeutschland - Paris; Wien - Frankfurt a/M - Köln - Vlissingen - London; Wien - Marienbad - Franzensbad - Carlsbad und Norddeutschland; Wien - Lemberg - Odessa - Kiew und Czernowitz - Jassy - Bukarest; Wien - Villach - Pontafel - Venedig - Rom, Wien 1892.

${ }^{14}$ Nielicznymi przykładami potwierdzającymi istnienie podobnych druków są: Rozkład jazdy koleja ważny od 1. maja 1907 r. czas środkowo-europejski [dot. połączeń z i do Stanisławowa - D.O.], [Stanisławów 1907]; Rozkład jazdy koleja wraz z taryfa jazdy do wszystkich stacyi obowiazujący od dnia 1. maja 1909 dla miasta Przemyśla, Przemyśl 1909.

15 Fahrplan über Verkehr der Züge auf der k.k. privil[egierte] Galicischen Carl Ludwig Bahn. Giltig vom 1. Oktober 1858, [b.m. 1858]; Rozkład jazdy parociagów, na kolei żelaznej Krakowsko-Górnoślaskiej od dnia 18 kwietnia 1848, [b.m. 1848]. ${ }^{16}$ Rozktad i ceny jazdy droga żelazną.
} 
konywano stosownych korekt w rozkładach jazdy ${ }^{17}$. Ów rytm starano się utrzymać także w okresie pierwszej wojny światowej ${ }^{18}$. Rzadko zarządzano inne terminy obowiązywania zmian ${ }^{19}$. Wydaje się też, że odejście od powyższych utartych terminów, w niektórych przypadkach wynikało z czysto komercyjnych względów ${ }^{20}$.

Lepiej zorganizowaną i przejrzystszą politykę informacyjną prowadzono na kolejach polskich po odzyskaniu niepodległości. Jednym z najpilniejszych zadań stojących przed władzami kolei było stworzenie spójnego i czytelnego rozkładu jazdy, który uwzględniałby żywotne interesy odbudowywanego państwa. Zadanie to nie należało do łatwych, zważywszy na stopień zniszczenia infrastruktury i taboru, brak spoistości komunikacyjnej między poszczególnymi częściami kraju i nierówny stopień zagęszczenia liniami kolejowymi. Dotkliwy był także niedobór wykwalifikowanej kadry zdolnej udźwignąć trud organizacyjny.

Już od pierwszych, powojennych lat wydawano drukiem pozycje, które swym zasięgiem miały objąć cały kraj² . Ukazywały się, zatem jednotomowe kompletne rozkłady jazdy ujmujące ruch na wszystkich liniach RP. Przyjęcie wspomnianej formuły było — z punktu widzenia pasażera chyba najlepszym rozwiązaniem, bo dawało mu pełną orientację w ofercie kolejowej; było to także, o czym nie należy zapominać, doskonałe posuniecie propagandowe polskich władz podkreślające - choć nie w każdym przypadku było to zasadne, niezawodność, niezależność i integralność ówczesnych kolei.

Wraz z rosnącą liczbą połączeń i jakością usług przewozowych, dotychczasowa formuła rozkładów zbiorczych dla całego kraju stawała się niekiedy nazbyt obszerna, a tym samym niepraktyczna. Dlatego też, już w kilka lat po uzyskaniu niepodległości, coraz częściej w powszechnym obiegu znajdowały się rozkłady dla poszczególnych okręgów komunikacyjnych, a także niektórych regionów i stacji, także tych położonych peryferyjnie. Z biegiem lat po to rozwiązanie sięgano częściej. Wydawano także pozycje zbiorcze, które grupowały stacje docelowe według jednego wspólnego kryterium (np. turystyka narciarska, uzdrowiskowa) ${ }^{22}$.

W okresie II RP, podobnie zresztą jak w czasie zaborów, masowo wydawano rozkłady w formie jedno- lub wieloarkuszowych plakatów ściennych, umieszczanych na stacjach i przystankach w widocznych punktach, w miejscach o dużym natężeniu ruchu podróżnych ${ }^{23}$. W obiegu znajdowały się ponadto rozkłady kieszonkowe, drukowane seriami rokrocznie lub okazyjnie przez przygodnych wydawców, na co dzień prowadzących zupełnie inną działalność.

\footnotetext{
${ }^{17}$ Rozkład jazdy koleją; por. także pozycje wymienione w przypisach $\mathrm{nr} 7$ i 8 . O istnieniu podziału na sezon letni i zimowy świadczą także inne pozycje. Por. Przewodnik kolejowy pótrocze 1892 r. zimowe, Warszawa [ok. 1891]; Schenkera pierwszy polski kurier kolejowy na sezon letni 1893. Z 2 mapami kolejowymi. Ważny od 1. czerwca 1893, III, 1893, Lwów 1893; Fahrplan über Verkehr.

${ }^{18}$ Rozkład jazdy (kolejowy) ważny od 1-go maja 1916, Przemyśl 1916.

19 Rozkład jazdy parociagów.

${ }^{20}$ Galicyjski rozkład jazdy. Z danych zamieszczonych na okładce rozkładu wynika, że było to już 21 wydanie tytułu w trzecim roku wydawnictwa. Okres jego ważności, przypadający tylko na trzy letnie miesiące (czerwiec-sierpień), był sztucznie zawężony przez wydawcę (inż. A. Jastrzębski). Inne zachowane rozkłady, wydane ok. 1914 r., nie potwierdzają konieczności tak częstego ich uaktualniania.

${ }^{21}$ Jako przykład można podać następujące pozycje: Rozkład jazdy pociagów wszystkich państwowych dróg żelaznych byłej: Galicji, Królestwa Kongresowego, Księstwa Poznańskiego, Śląska Cieszyńskiego oraz kolejach podjazdowych z uwzględnieniem ostatnich zmian, R. 1, wyd. 6, październik 1919, Warszawa [1919]; [Rozkład jazdy ważny od 1 czerwca 1922 r.], Warszawa [1922]; Rozkład jazdy polskich Kolei państwowych „Pekape” z uwzględnieniem ostatnich zmian, R. 1, wyd. 1, [ważny od lipca 1921], Warszawa [1921].

${ }_{22}$ Por. Bezpośrednie połaczenia turystyczne do górskich stacji sportów zimowych 1937/38 r., [b.m. 1937?].

${ }^{23}$ Szczegółowe zalecenia odnośnie wyglądu rozkładów ściennych, elementów i zastosowanych oznaczeń, trybu ich wprowadzania odnajdujemy w okólnikach i rozporządzeniach kompetentnych ministerstw (w latach: 1921-1924 — Ministerstwo Kolei Żelaznych, 1924-1926 - Ministerstwo Kolei, 1926-1939 - Ministerstwo Komunikacji) rozsyłanych do poszczególnych dyrekcji (D.K.P. i D.O.K.P.). Dziennik Urzędowy Ministerstwa Kolei Żelaznych [dalej: DzUMKŻ], 1 czerwiec 1921, nr 16, poz. 47, s. 2-6; DzUMKŻ, 31 marzec 1924, nr 6, poz. 26, s. 87-88; Dziennik Urzędowy Ministerstwa Komunikacji [dalej: $D z U M K$ ], R. 20, 13 kwiecień 1938, nr 29, poz. 276, s. 492-496; DzUMK, R. 20, 4 kwiecień 1938, nr 27, poz. 256 , s. 448.
} 
W latach 1919-1939 rozkłady wydawano zazwyczaj w cyklach: letnim (maj/czerwiec — wrzesień/ październik) i zimowym (wrzesień/październik — maj/czerwiec roku następnego). Pod koniec II RP w obiegu pojawiły się urzędowe rozkłady jazdy wydawane w trzech przedziałach: letnim, jesiennym i zimowym ${ }^{24}$. Wydaje się jednak, że cykl jesienny obowiązywania rozkładów jazdy nie przyjął $\operatorname{się}^{25}$. W obiegu znajdowały się również edycje noszące inne datacje, np. luty $1919^{26}$, jak też i pozycje wydane okazjonalnie (jubileusz, impreza sportowa, uroczystość), niezależnie od utartych terminów wydawniczych ${ }^{27}$.

Politykę komunikacyjną II RP w pierwszych latach niepodległości cechował wszechobecny chaos $^{28}$, szczególnie dotkliwy w latach 1919-1921. Ogarnął on także sferę edytorsko-informacyjną prowadzoną na kolejach ${ }^{29}$. Niespodziewane zmiany w organizacji ruchu pociągów wymuszały działania wojenne prowadzone $\mathrm{z}$ bolszewicką Rosją oraz olbrzymie kłopoty z infrastrukturą i taborem ${ }^{30}$. Skutkowało to zamętem w planowaniu i wydawaniu rozkładów jazdy. Dopiero zakończenie wojny polsko-bolszewickiej w 1920 r. pozwoliło rozpocząć spokojną pracę nad organizacją komunikacji pasażerskiej wewnątrz kraju i w połączeniach zagranicznych ${ }^{31}$.

Wydaje się, że zmiany w kursowaniu pociągów nie zawsze pociągały za sobą konieczność druku nowego rozkładu jazdy. Często praktykowanym posunięciem było naklejanie na ówczesne rozkłady pasków papieru z naniesionymi zmianami ${ }^{32}$. Rozwiązanie to wpisywało się w politykę obniżania kosztów, podejmowaną przez państwo w okresie wstrząsów i kryzysów gospodarczych. Sanowanie finansów kolei skutkowało cięciem wydatków na szerszą skalę, np. ograniczano rozdawnictwo rozkładów urzędowych i wprowadzano częściową lub całkowitą odpłatność za nie. Nieplanowane zmiany w ruchu pociągów nie zawsze były następstwem oszczędności; wymuszały je niekiedy olbrzymie braki w ta-

${ }^{24}$ Okres jesienny 1937. Urzędowy rozkład jazdy i lotów. Z załącznikiem. Ważny od 6 września 1937 r. do 14 grudnia 1937 r. Zawiera rozkłady jazdy Polskich Kolei Państwowych i kolei prywatnych, rozkłady lotów w komunikacji wewnętrznej i z zagranica, oraz komunikacji morskiej, Warszawa-Poznań-Kraków-Lwów-Łódź-Gdańsk [1937]. Z informacji zawartych w niektórych najstarszych rozkładach okresu międzywojnia wynika, iż w pierwszych latach po odzyskaniu niepodległości, zmiany w organizacji ruchu następowały kilka razy w roku. Dowodzi tego chociażby wzmianka o liczbie wydań (sześć, stan na październik 1919 r.) w pierwszym roku obecności na rynku pozycji pt. Rozkład jazdy pociągów wszystkich.

${ }^{25}$ Z ministerialnych wytycznych jednoznacznie wynika, że już w 1938 r. obowiązywały dwa okresy ważności rozkładów: letni trwający od 15 maja do pierwszej soboty października oraz zimowy, liczony od pierwszej niedzieli października do 14 maja następnego roku. Zob. DzUMK, R. 20, 13 kwiecień 1938, nr 29, poz. 276, s. 495.

${ }^{26}$ Rozklad jazdy polskich kolei państwowych (sezon zimowy 1918-19), [b.m.] 1918.

27 Dodatkowe pociagi na uroczystości Bożego Ciała w Lowiczu dnia 8 czerwca 1939 roku, [b.m.] 1939; Na Zjazd w 25-ta rocznicę czynu Legionów Polskich w dniu 6 sierpnia 1939 roku Dyrekcja Okręgowa Kolei Państwowych w Poznaniu uruchamia następujące pociagi popularne do Krakowa, Poznań [1939]. Okazją do wydania nietypowego rozkładu jazdy miały być także narciarskie mistrzostwa świata FIS w Zakopanem w lutym 1939 r. Zob. anonse w: Rozklad jazdy III-go okręgu komunikacyjnego. Ważny na okres zimowy od 9.I.1939 do 14.V.1939, Warszawa 1939, s. 105; Okres zimowy 1938/1939. Urzędowy rozkład jazdy i lotów. Z załacznikami: komunikacja samochodowa P.K.P. i ruch świąteczny (Boże Narodzenie $i$ Wielkanoc). Ważny od 2 października 1938 r. do 14 maja 1939 r. Zawiera rozkłady jazdy Polskich Kolei Państwowych $i$ kolei prywatnych, rozkłady lotów w komunikacji wewnętrznej i z zagranica, żeglugi morskiej i rzecznej, Warszawa-Poznań-Kraków-Lwów-Łódź-Gdańsk [1938], s. passim.

28 Z. Taylor, Rozwój i regres sieci kolejowej w Polsce, Warszawa 2007, s. 47-48.

${ }^{29}$ D. Opaliński, Kolejowe rozkłady jazdy, s. 327.

${ }^{30}$ Por. m.in.: A. Paszke, M. Jerczyński, S.M. Koziarski, 150 lat Drogi Żelaznej Warszawsko-Wiedeńskiej, Warszawa 1995, s. 257-259; M. Pisarski, Koleje polskie 1842-1972, Warszawa 1974, s. 65-66.

${ }^{31}$ Planowanie połączeń zagranicznych koordynowały od 1920 r. „europejskie konferencje rozkładu jazdy”, w których Polska regularnie brała udział. Gospodarzem pierwszego spotkania było Brno. Zob. J. Grabiański, Ruch pasażerski na Polskich Kolejach Państwowych, w: 20-lecie komunikacji w Polsce Odrodzonej, Kraków 1939, s. 192.

${ }^{32}$ DzUMKŻ, 1 czerwiec 1921, nr 16, poz. 46, s. 1-2, gdzie czytamy: ,[...] polecam [okólnik podpisał minister Jasiński — D.O.] z natychmiastową ważnością ściśle stosować i zachować największą oszczędność przy ustalaniu nakładu" oraz DzUMKŻ, 1 lipiec 1921, nr 17, poz. 54, s. 2-3. W okólniku tam ogłoszonym, apel wzywający do oszczędności został ponowiony: „Wzrastająca drożyzna papieru i druku obciąża w wysokim stopniu budżet kolejowy i zmusza M[inisterstwo] K[olei] Ż[elaznych] do przestrzegania najdalej idącej ekonomii”. Zalecenia ministerialne pozostawały w ścisłym związku z trudną sytuacją gospodarczą całego kraju. 
borze $^{33}$. Stan ten, charakterystyczny dla pierwszych powojennych lat, utrzymywał się także w późniejszym okresie, co uniemożliwiało stabilizację przewozów i obniżało zaufanie pasażerów do przewoźnika państwowego. Problem próbowano rozwiązać na szczeblu ministerialnym, czasowo ograniczając pełną dowolność w nanoszeniu zmian przez poszczególne dyrekcje. Wszelkie projektowane przez nie korekty w obowiązującym rozkładzie jazdy, musiały wpierw uzyskać aprobatę Ministerstwa Kolei ${ }^{34}$.

Edycją kolejowych rozkładów jazdy często zajmowały się podmioty powiązane z kolejami. Tak było zarówno w okresie zaborów, jak i w niepodległej już Polsce. Z grona podobnych wydawców działających do 1918 r. należałoby wymienić np.: Selbstverlage der k.k. General-Direction der Österreichische Staatsbahnen, wydawnictwo Emila Hinglera emerytowanego starszego inspektora c.k. kolei państwowych we Lwowie, a z czasów II RP Polskie Towarzystwo Księgarni Kolejowych „Ruch”, które przez znaczną część międzywojnia posiadało w Polsce monopol na wydawanie urzędowych rozkładów jaz$\mathrm{dy}^{35}$. Wspomniane podmioty specjalizowały się w edytorstwie objętościowo pokaźnych pozycji, zasięgiem obejmujące wszystkie linie podległe poszczególnym dyrekcjom. „Ruch” wydawał także rozkłady okręgowe oraz pozycje kieszonkowe dla stacji węzłowych i przelotowych o dużym natężeniu ruchu.

Pozostali wydawcy tworzą grupę bardzo zróżnicowaną, znajdują się w niej zarówno firmy niezależne, o uznanej juz marce, mające już pewne doświadczenie w szeroko rozumianej branży księgarsko-wydawniczej (np. oficyny: Marii Ostaszewskiej z Warszawy i J. M. Himmelblaua z Krakowa, Józefa Styfiego z Przemyśla), jak też i wydawcy bez specjalnej wprawy i zaplecza edytorskiego (właściciele pensjonatów, kupcy, stowarzyszenia). Ci ostatni, przygodni edytorzy, trudnili się zwykle wydawnictwem rozkładów „portfelowych” i broszurowych. Wydaje się, że z przyczyn technicznych owa grupa nie była predestynowana do redakcji pozycji bardziej ambitnych — przynajmniej w kilku pierwszych powojennych latach ${ }^{36}$. Wśród podmiotów wydawniczych należałoby dostrzec także niezależne firmy specjalizujące się w różnych drukach kolejowych, np. T. i W. Rakowscy, W. K. Walter, prawdopodobnie też inż. A. Jastrzębski.

Poważne trudności pojawiają się przy ustalaniu autorstwa rozkładów. Ich opracowywaniem trudniły się często liczne komitety redakcyjne, co poświadczają stosowne dopiski wewnątrz samych źródeł. Ze względu na charakter źródła wydaje się, że znaczna część rozkładów anonimowych mogła być efektem zbiorowych poczynań (dotyczy to całego okresu objętego badaniami). Autorstwo około 15-20\% wszystkich rozkładów wydanych w czasie zaborów nie budzi wątpliwości - sygnują je osoby znane z imienia i nazwiska ${ }^{37}$. Zdecydowana większość z nich to osoby dziś już jednak anonimowe, o których próżno szukać wzmianki w ogólnodostępnych kompendiach biograficznych.

W okresie II RP odsetek rozkładów sygnowanych przez autorów wyraźnie uległ obniżeniu. Spośród pozycji objętych analizą, tylko jedną można przypisać konkretnej osobie ${ }^{38}$. Wydaje się, że ten

\footnotetext{
33 J. Grabiański, Ruch pasażerski, s. 93.

${ }^{34}$ Dziennik Urzędowy Ministerstwa Kolei [dalej: DzUMKol], 27 czerwiec 1925, nr 8, poz. 19, s. 162.

35 Pierwszy z takowych rozkładów ukazał się drukiem dopiero w 1922 r. (obowiązywał od 1 czerwca). Szerzej na temat rozległej działalności handlowej, marketingowej i wydawniczej „Ruchu” pisał M. Bryja, Polskie Towarzystwo Księgarń Kolejowych „Ruch”, „Z Badań Nad Polskimi Księgozbiorami Historycznymi” 19, 1999, s. 19-64. Niestety, wydawnictwo rozkładów jazdy zostało przez Bryję potraktowane marginalnie (s. 48-49).

${ }^{36}$ Potwierdza to chociażby uwaga jednego z wydawców, wyjaśniająca przyczyny opublikowania niekompletnego rozkładu jazdy. Zob. Express. Rozkład jazdy polskich kolei państwowych, [b.m.] 1921.

37 Zob. np.: W. K. Walter, Rozkład jazdy pociagów pasażerskich na kolejach żelaznych w Królestwie Polskiem i przylegajacych. Sezon letni obowiazujacy od dnia 18 kwietnia (1 maja) 1911 r. Zebrat i wydał..., Warszawa 1911; tenże, Rozkład jazdy pociąów pasażerskich na kolejach żelaznych w Królestwie Polskiem i przylegających. Sezon letni obowiazujący od dnia 18 kwietnia (1 maja) 1906 r. Zebrat $i$ wydat..., Warszawa 1906; E. Kossonoga, Przewodnik kolejowy dla Galicji i Bukowiny do miejsc kapielowych w kraju i zagranica oraz do ważniejszych miejscowości Europy Środkowej z mapa pogladowa. Uło$\dot{z} y ł \ldots . .$, Kraków 1892. Swoje przewodniki (rozkłady) sygnowali ponadto: Wacław Rakowski, a także Bronisław Pietrzykowski, Czaplicki, Szerzeniewski, J. Schenker, Urban Massalski i Jan Bauer.

${ }^{38}$ Z. Hoffmann z Gniezna, Wielki rozkład jazdy polskich kolei państwowych oraz kolejek podjazdowych, z objaśnieniami, spisem stacji i specjalna mapa ważna na rok 1922. Zebrat i opracowat wedtug urzędowych źródeł..., Warszawa-Poznań-Kraków-Lwów-Gdańsk-Wilno [b.r.].
} 
nagły spadek mógł być wywołany generalną zmianą zasad obowiązujących podczas redagowania rozkładów jazdy. Przygotowanie druku zawierającego zbiorczy rozkład jazdy przerastało siły jednej osoby, za ich redakcję brały się, zatem większe zespoły w tym celu powołane. Sądzę, że w ten oto sposób została opracowana zdecydowana większość anonimowych pozycji. Jak w praktyce w okresie międzywojnia wyglądał proces powstawania owych druków?

Odpowiedzialność za przygotowanie rozkładów jazdy spoczywała na poszczególnych dyrekcjach, te zaś zadanie to zlecały stosownym wydziałom i ich wyspecjalizowanym komórkom, zajmującym się ruchem, eksploatacją ${ }^{39}$. Organem nadzorującym cały proces, nadającym całemu przedsięwzięciu ramy prawne było stosowne ministerstwo administrujące kolejami, które poprzez okólniki i rozporządzenia określało w detalach wygląd samych rozkładów jazdy, tryb ich wprowadzania, czas obowiązywania oraz inne edytorskie szczegóły ${ }^{40}$. Wydaje się, że ostateczny kształt rozkładów musiał być konsultowany z innymi dyrekcjami tak, by był on spójny także w szerszym ujęciu. Należało sprawdzić dostępność taboru i infrastruktury, wykluczyć konflikt interesów między dyrekcjami i wyeliminować dublowanie połączeń. Od strony wydawniczej podmiotem odpowiedzialnym za druk rozkładów urzędowych był od 1922 r. wspomniany już PTKK „Ruch”. Wydaje się, że kosztami edycji obciążane były także same dyrekcje, co poświadczają zachowane w archiwach wzmianki źródłowe ${ }^{41}$. Trudno jednoznacznie orzec, czy praktyki stosowane w D.O.K.P. w Katowicach w latach 1930-1932 były powszechne także w innych dyrekcjach w całym analizowanym okresie ${ }^{42}$.

Odbiór społeczny kolejowych rozkładów jazdy zależny był od ich nakładu, ceny i zasad dystrybucji. $Z$ braku pewnych danych nie sposób dziś precyzyjne określić rozmiary dziewiętnastowiecznych edycji. Przydatne w orientacyjnych szacunkach mogą być uśrednione dane dotyczące nakładów druków użytkowych. Dla okresu międzywojnia, nieocenionym źródłem informacji w tej materii, są odręczne dopiski na egzemplarzach znajdujących się w zbiorach Biblioteki Narodowej. Powstały one w oparciu o dane pochodzące z kancelarii starostów, odpowiedzialnych w okresie II RP za dostarczenie do Biblioteki Narodowej obowiązkowego egzemplarza druku, wydanego na podległym im obszarze $^{43}$. Dopiski te pomocne są także w ustalaniu miejsca i roku wydania pozycji.

$\mathrm{Na}$ jakim, zatem poziomie kształtowały się, w interesującym nas okresie, nakłady kolejowych rozkładów jazdy? Do lat 70-80. XIX w., średni nakład druków użytkowych wahał się w przedziale od 500 do 1000 egzemplarzy. W tym też przedziale należałoby sytuować omawiane edycje. Patrząc jednak na udokumentowane nakłady rozkładów z okresu późniejszego (II RP), wydaje się, że interesujące nas edycje oscylowały raczej w pobliżu dolnej granicy, czyli 500 egzemplarzy. Kolejne dziesięciolecia przyniosły znaczący wzrost nakładów wszelkich druków, także tych o utylitarnym charakterze. Szacuje się, że na przełomie XIX i XX w. średni nakład druków użytkowych kształtował się na poziomie od 1000 do 3000 egzemplarzy. Sądzę, że także i w tym okresie, edycje rozkładów nie przekraczały znacząco owej dolnej uśrednionej granicy ${ }^{44}$.

Dla okresu międzywojnia dysponujemy już w miarę dokładnymi danymi. Średni nakład broszurowych rozkładów wydawanych przez PTKK „Ruch” wahał się od 3000 (np. dla Katowic) do 5000 eg-

\footnotetext{
${ }^{39} \mathrm{~W}$ obliczu nowych źródeł należy zweryfikować opisany przeze mnie przed laty mechanizm powstawania urzędowych rozkładów jazdy w II RP. Por. D. Opaliński, Kolejowe rozkłady jazdy, s. 330.

${ }^{40}$ Por. $D z U M K \dot{Z}$, 1 czerwiec 1921, nr 16, poz. 47, s. 2-6; DzUMKŻ, 31 marzec 1924, nr 6, poz. 26, s. 87-88; DzUMK, R. 20, 13 kwiecień 1938, nr 29, poz. 276, s. 492-496; DzUMK, R. 20, 4 kwiecień 1938, nr 27, poz. 256, s. 448.

${ }^{41}$ Archiwum Państwowe w Katowicach [dalej: APK], Urząd Kontroli Państwowej w Katowicach, zespół nr 28, sygn. 443, s. 86 .

${ }^{42} \mathrm{Z}$ ministerialnego okólnika datowanego na maj 1921 r. nie wynika wyraźnie, kto finansował rozkłady jazdy. Zob. $D z U M K \dot{Z}$, 1 lipiec 1921, nr 17, poz. 54, s. 3.

${ }^{43}$ Egzemplarze nadsyłano nieregularnie, stąd znaczne luki w zasobie Biblioteki Narodowej.

${ }^{44} \mathrm{Na}$ temat uśrednionych nakładów pisali m.in.: A. Pilak, $Z$ dziejów upowszechniania książki w Rzeczypospolitej Krakowskiej (1815-1846), „Roczniki Biblioteczne” 19, 1975, z. 3-4, s. 363; Cz. Erber, Dzieje książki na Kielecczyźnie w latach 1795-1865, Kielce 1996, s. 58; S. Arct, E. Pawłowska, Wydawcy warszawscy w latach 1878-1914. (Szkic do dziejów wydawnictw książek w Polsce), w: Z dziejów książek i bibliotek w Warszawie, red. S. Tazbir, Warszawa 1961, s. 366.
} 
zemplarzy (np. dla Krakowa, Ciechocinka). Wydaje się, że wraz z dodrukami, nakład niektórych tytułów przekroczył próg 10000 egzemplarzy ${ }^{45}$. Niewiele ukazało się pozycji, które już w pierwodruku zbliżyły się do tego poziomu ${ }^{46}$ lub go znacząco przekroczyło ${ }^{47}$. Szanse na rozprzedaż dużych nakładów wzrastały przy drukach objętościowo skromnych i teoretycznie tańszych, oraz wydanych w powiązaniu z inną lokalną inicjatywą (np., jako dodatek do gazety lub druku reklamowego ${ }^{48}$ ). $\mathrm{Na}$ wysokie, regularne edycje w okresie II RP mógł sobie pozwolić jedynie PTKK „Ruch”, który posiadał rozbudowaną sieć punktów sprzedaży oraz wieloletnie doświadczenie w tej branży. Edycje finansowane przez pozostałych prywatnych wydawców zwykle osiągały mniejsze rozmiary (od 1000 do 3000 egzemplarzy $)^{49}$. Wydaje się, że rozkłady dla obszarów peryferyjnie położonych i słabo skomunikowanych, szczególnie na wschodnich rubieżach RP, osiągały jeszcze niższe nakłady ${ }^{50}$. Afiszowe rozkłady jazdy, wywieszane na stacjach i w innych miejscach publicznych, wydawano w pierwodruku nawet w 2000-2200 egzemplarzach ${ }^{51}$.

Spójrzmy na ceny rozkładów jazdy. Z uzyskanych danych wynika, iż przez cały okres objęty badaniami, interesujące nas pozycje osiągały przystępne ceny. Rozkłady książkowe wydane w pierwszych latach niepodległości kosztowały średnio od 3,50 do 4,00 marek. Druki wydane dekadę później ceniono na około 4,5-5 złotych, osiągając tym samym najwyższe wartości w całym dwudziestoleciu międzywojennym. W ostatnim pięcioleciu międzywojnia, objętościowo zbliżone pozycje wyceniano już jedynie na około 3 złote, co wiązać należy z zaplanowaną przez „Ruch” akcją umasawiania wydawanych druków ${ }^{52}$. Działania te nie pozostały bez wpływu na charakter rozkładów. Wraz z obniżką cen zanikł np. autorski charakter ilustracji zamieszczanych w analizowanych źródłach. W ich miejsce na stałe zagościł banał i sztampa typowa dla wysokonakładowych druków, schlebiających masowym gustom odbiorców.

Broszurowe rozkłady były relatywnie tańsze. Pozycje z początku 1919 r. oferowano za 75 fenigów, zaś rozkład wydany w połowie 1924 r. wyceniono na 50 marek. Ceny kieszonkowych rozkładów opublikowanych przez PTKK „Ruch” oraz prywatne oficyny w okresie od schyłku lat 20. do końca następnego dziesięciolecia, kształtowały się na poziomie 20-30 groszy. Ceny rozkładów w okresie zaborów także należały do przystępnych, nie przekraczały zwykle 1 korony lub 0,5 złr. (w Galicji) i 1 rubla (w Królestwie Polskim).

\footnotetext{
${ }^{45}$ Szerzej na ten temat D. Opaliński, Kolejowe rozkłady jazdy, s. 328-329.

${ }^{46}$ W liczbie 10000 egzemplarzy wydano: Letni rozkład jazdy kolei i kolejki, Warszawa [1929]; Wielkopolsko-pomorski rozkład jazdy ważny na okres zimowy 1928/29 r., Warszawa-Poznań-Kraków-Lwów-Wilno-Gdańsk-Katowice [1928]; Turystyczny rozkład jazdy, ważny na okres letni od 15.V. do 6.X. 1934 r., Warszawa-Poznań-Kraków-Lwów-Łódź-Gdańsk [1934].

47 Por. Kieszonkowy ogólny rozkład jazdy pociagów dalekobieżnych, podmiejskich, dojazdowych, elektrycznej kolei dojazdowej Warszawa-Grodzisk oraz rozkład lotów na sezon letni 1931 r., Warszawa 1931, (wydany w 25000 egzemplarzach); Ruch kolejowy Kuriera Poznańskiego na sezon latowy 1930 (bez gwarancji), [b.m.] 1930, (nakład 55000 egzemplarzy). Bardziej szczegółowych danych dostarcza nam pokontrolne sprawozdanie przechowywane w APK, Urząd Kontroli Państwowej w Katowicach, zespół nr 28, sygn. 443, s. 86. Cywilny rozkład jazdy wydany przez D.O.K.P w Katowicach, prawdopodobnie w 1932 r., osiągnął nakład 21100 egzemplarzy. W ciągu tego samego roku katowicka dyrekcja sfinansowała także druk 12150 sztuk rozkładów służbowych, 3160 wykresów, będących graficznym ich uzupełnieniem oraz 600 egzemplarzy rozkładów wojskowych. Koszty druku wszystkich wspomnianych pozycji wyniosły 70.599,16 zł.

${ }^{48}$ Ruch kolejowy Kuriera Poznańskiego; Kilka słów o Pasażu Bielaka oraz kolejowy rozkład jazdy ważny od 3 września 1936, Kraków 1936.

${ }^{49}$ Zob. Rozkład jazdy pociagów dla Drohobycza, Borysławia i Truskawca z uwzględnieniem wszelkich połaczeń krajowych i zagranicznych ważny od 15. maja 1928, Drohobycz [1928]; Bezpłatny rozkład jazdy i informator m[iasta] Białegostoku i Grodna, Białystok 1930; Najnowszy spis jarmarków na rok 1930 województwa poznańskiego, pomorskiego i śląskiego oraz rozkład jazdy (odjazdy pociagów z Poznania), Poznań [1929]; Najnowszy bezpłatny rozkład jazdy kolejowej, automobilowej i komunikacji lotniczej na sezon letni rok 1928, Kraków 1928.

${ }^{50}$ Rozkład jazdy na województwo wołyńskie ważny od 15 maja 1929 r., [Łuck 1929]. Pozycja ukazała się w nakładzie 500 egzemplarzy.

${ }^{51}$ Np. Francusko-Polskie Tow[arzystwo] Kolejowe. Rozkład jazdy ważny od 15.V.1938. (Katowice)-Herby Nowe-Gdynia, Bydgoszcz [1938].

${ }_{52}$ M. Bryja, Polskie Towarzystwo Księgarń Kolejowych „Ruch”, s. 48-49.
} 
Reasumując, druki poddane analizie nie odbiegały cenowo od innych, podobnych objętościowo pozycji użytkowych, znajdujących się w obiegu w XIX i w pierwszej połowie XX w. Mimo niewygórowanej ceny, były to publikacje adresowane dla raczej lepiej sytuowanych użytkowników kolei, o stałych i pewnych dochodach ${ }^{53}$. Wydaje się, że naturalnymi odbiorcami rozkładów jazdy były osoby korzystające z usług kolei regularnie, przemieszczające się na dłuższych dystansach, dokonujące przesiadek. Można przypuszczać, że społeczność tę tworzyła inteligencja, złożona z urzędników i wojskowych odbywających podróże służbowe, arystokracja i ziemiaństwo zmierzające na wypoczynek letni, do wód, w kraju i za granicą. Odbiorców rozkładów należy szukać także wśród drobnomieszczaństwa, które wykazywało się w analizowanym okresie dużą mobilnością, związaną nie tylko z wykonywaną profesją, ale także zmianą sposobu spędzania wolnego czasu. Moje przypuszczenia w tej materii potwierdzają niektóre tytuły rozkładów jazdy oraz sama ich zawartośćs ${ }^{54}$. Ważną wskazówką są także ministerialne wytyczne obwieszczane w dziennikach urzędowych, z których jednoznacznie wynika, że rozkłady jazdy trafiały bezpłatnie do urzędów, głównie wojskowych i pocztowych ${ }^{55}$.

Rozkłady z okresu objętego badaniami nie imponowały szatą graficzną. Oszczędność form wynikała z odgórnych zaleceń, w których organ nadrzędny (np. ministerstwo) określał kolor tła, dozwolone symbole, brzmienie nagłówków oraz konstrukcję samej tabeli ${ }^{56}$. Powyższe wytyczne bardzo ograniczały pole manewru osobom odpowiedzialnym za ich wygląd (projektantom, grafikom). Zdecydowana większość źródeł poddanych analizie charakteryzuje się prostym, przejrzystym układem, złożonym $\mathrm{z}$ jasnego tła, na którym umieszczono rubryki z danymi, utrzymanymi w ciemnej, odcinającej się od podłoża kolorystyce (od szarości do czerni). Trwałość przyjętych rozwiązań pozwala przypuszczać, że w XIX i XX wieku, mimo istnienia w obu stuleciach odmiennych wzorców estetycznych, sięgano po bardzo podobne, nieomal identyczne koncepcje. Do rzadkości należą pozycje, które wyłamywały się z obowiązującego szablonu ${ }^{57}$. Wspomniane pozycje, mimo iż na tle innych rozkładów wyróżniały się szatą graficzną, pod względem czytelności ustępowały tradycyjnemu, tabelarycznemu układowi. Po nietypowe rozwiązania sięgano nader rzadko.

W powszechnym mniemaniu rozkłady jazdy są źródłem nudnym, mało efektownym, sporadycznie wykorzystywanym; nawet historycy zajmujący się dziejami kolejnictwa, traktują je z wyczuwalnym dystansem i nieufnością.

Trzeba wyraźnie zaznaczyć, że dawne rozkłady jazdy zawierają nie tylko ciągi danych o planowych połączeniach. Oprócz tych podstawowych informacji znajdujemy tam także fragmenty przepisów kolejowych, taryfy przewozowe, rady praktyczne dla podróżnych, czy działy reklamowe, co znacząco podnosi atrakcyjność źródła i poszerza paletę możliwości badawczych.

Podstawową funkcją każdego rozkładu jazdy jest informowanie ich odbiorców o porządku jazdy pociągów. Wiedza ta zaś, jest przydatna głównie w organizowaniu podróży. Dzięki rozkładom możemy w miarę precyzyjnie odtworzyć przebieg podróży, czas jej trwania i liczbę przesiadek. Obserwacje czynione poprzez dziesięciolecia obrazują zmiany realnie wpływające na komfort i tempo podróży.

\footnotetext{
53 Zob. Z. Landau, J. Tomaszewski, Gospodarka Polski międzywojennej 1918-1939, t. 1-4, Warszawa 1967-1989. Szczegółowe dane na temat zarobków i cen produktów pierwszej potrzeby znajdują się w: t. 1, s. 124-132, 181-196; t. 2, s. 96-105, 161-184; t. 3, s. 109-114, 131-143, 212-243; t. 4, s. 176-183, 202-214, 307-332. Zob. też S. Hoszowski, Ceny we Lwowie w latach 1701-1914, Lwów 1934, S. Siegel, Ceny w Warszawie w latach 1816-1914, Poznań 1949, M. Górkiewicz, Ceny w Krakowie w latach 1796-1914, Poznań 1950.

${ }^{54}$ Najnowszy spis jarmarków na rok 1930; Kilka słów o Pasażu Bielaka; Brześć n. Bugiem. Informator rodziny wojskowej. Mały rozkład jazdy pociagów ważny od 15.XII.1937 r. Kalendarzyk na rok 1938, Brześć 1938; por. zawartość rozkładów urzędowych np.: [Rozkład jazdy ważny od 1 czerwca 1922 r.]; Urzędowy rozklad jazdy. Okres letni 1931. Ważny od 15 maja 1931 r., Warszawa [1931].

${ }_{55} \mathrm{Dz} U M K \dot{Z}$, nr 17, 1 lipiec 1921, nr 17, poz. 54, s. 3.

${ }^{56} D z U M K, 13$ kwiecień 1938, nr 29, poz. 276, s. 492-496.

57 Por. wileńskie rozkłady z końca lat 20. XX w. przechowywane w Czytelni Dokumentów Życia Społecznego Biblioteki Narodowej w Warszawie, sygn.: XIIA2al rozkłady jazdy wg miast ścienne T, W; Bezpośrednie połaczenia turystyczne. Szerzej na ten temat zob. D. Opaliński, Kolejowe rozkłady jazdy, s. 329-330.
} 
W badaniach tego typu, rozkłady jazdy należy uznać za materiał o pierwszorzędnym znaczeniu. Istotny $\mathrm{w}$ tego typu badaniach jest czas trwania i miejsce planowych postojów, precyzyjnie ujętych w rozkładach. Z zachowanych relacji podróżnych wynika, iż dłuższe przerwy wykorzystywano na posiłek, załatwianie potrzeb fizjologicznych, krótką przechadzkę lub kurtuazyjne rozmowy. Na podstawie danych pochodzących z rozkładów można by uściślić, gdzie konkretnie podróżni mogli liczyć na dłuższe wytchnienie, nowe znajomości i obfitszy posiłek, gdzie zaś tylko zaspokajano najpilniejsze potrzeby sanitarne i aprowizacyjne. Z pobieżnej analizy wynika, iż czas trwania postojów z upływem lat wyraźnie się skracał, malała także liczba stacji, na których przerywano jazdę. To wszystko dowodzi, że już na początku XX wieku podróż koleją coraz bardziej stawała się czynnością schematyczną, pozbawioną pierwiastka przygody i niepewności, nabierając stopniowo cech podróży znanej ze współczesności.

Rozkłady są źródłem, które niesłusznie pomija się w badaniach nad organizacją pracy na kolei. Dzięki nim można dokładnie śledzić zmiany w natężeniu ruchu i bez kłopotów sytuować je w czasie i przestrzeni. Czas trwania i częstotliwość postojów jest nie tylko wymownym świadectwem tego, jak pasażerowie spędzali podróż, dzięki tym informacjom możemy próbować zrekonstruować przebieg i tempo pracy kolejarzy przy obsłudze pociągu. Uzupełnianie zapasów węgla i wody wymagało czasu, podobnie jak i załadunek oraz wyładunek bagaży, przesyłek. Czas postojów wykorzystywano także do przetaczania wagonów, parowozów, a także dopinania ich do składów znajdujących się już w ruchu. W trakcie postojów następowała także zmiana obsługi pociągów. Skracanie czasu niezbędnego do obsługi składu obrazuje realny postęp i doskonalenie czynności stricte kolejarskich.

Tempo przejazdu dostarcza nam również wiedzy o osiągach technicznych dawnych kolei. Dzięki danym pochodzącym z różnych okresów możliwe by było ustalenie średnich prędkości dla poszczególnych odcinków, o różnym przecież ukształtowaniu terenowym. Należałoby zastanowić się, czy na tempo jazdy nie wypływały inne niezależne od kolei czynniki, np. warunki pogodowe czy aktualna sytuacja polityczna. Wnioski uprawniałyby zaś pośrednio do stawiania pytań o stan infrastruktury kolejowej (głównie torowisk) oraz taboru. Wydaje się, że konkluzje wypływające z zestawienia owych danych znacząco wzbogaciłyby naszą wiedzę o możliwościach technicznych najstarszych kolei.

W oparciu o dawne rozkłady można w miarę precyzyjnie odtworzyć stan gastronomii kolejowej. Znaczna część wykorzystanych przeze mnie źródeł zawiera nie tylko wskazówki świadczące o istnieniu danego punktu, ale informuje nas szerzej także o kategoryzacji usług świadczonych na kolejach. W przypadku braku jakichkolwiek danych o istnieniu niektórych lokali dworcowych — co często ma miejsce, wzmianki te nabierają szczególnego znaczenia ${ }^{58}$.

Obecność w rozkładach wyciągów z taryf kolejowych sprawia, że charakteryzowane źródło może być pomocne $\mathrm{w}$ badaniach nad polityką taryfową państw zaborczych. Rozkłady zawierają ponadto szczegółowe przepisy przewozowe, co pozwala doskonale śledzić panujący na kolejach porządek, z punktu zarówno pasażerów, jak i obsługi. Wszelkie regulaminy, przepisy, instrukcje obrazują nam nie tylko pewne regulacje obowiązujące na kolei, ale również realne problemy ówczesnych podróżnych.

Na podstawie rozkładów jazdy można także wnioskować o kierunkach wojaży podejmowanych w XIX i pierwszej połowie XX wieku. Za przykład mogą nam posłużyć fragmenty zawierające porządek jazdy pociągów na wybranych szlakach zagranicznych. Zmienność lub trwałość owych zestawień jest wymownym świadectwem dawnych preferencji użytkowników kolei, a także państwa, które wydaje się, iż w ten sposób kreowało oczekiwane postawy społeczne.

Oprócz tej wspomnianej funkcji rozkłady wykorzystywano, jako swoiste medium komentujące bieżące i ważkie wydarzenia natury gospodarczej, politycznej czy społecznej. Jako przykład można podać działania kolei z okresu wczesnej II RP, gdy sztucznie zwiększano liczbę połączeń między stolicą a ówczesnymi centrami Rzeczypospolitej. Posunięcie to miało czysto propagandowy wydźwięk. Intencją państwa było stworzenie wrażenia prężności i spoistości systemu komunikacyjnego II RP,

${ }_{58}$ Por. D. Opaliński, Usługi gastronomiczne na kolejach galicyjskich, Kwart. HKM 2001, nr 3, s. 209-220. 
podczas gdy w rzeczywistości mieliśmy do czynienia z układem pełnym niedoskonałości, gdzie dawne podziały zaborcze wciąż dawały o sobie znać. Ranga, jaką nadano w rozkładach Gdańskowi, Górnemu Śląskowi i całej ścianie zachodniej dowodzi, że druki poddane analizie, oprócz funkcji czysto utylitarnej, miały za zadanie podkreślać polskość i integralność tych ziem z resztą odbudowującego się kraju. Śmiałość, z jaką wkraczano — poprzez rozkłady — na obszar Górnego Śląska zajęty przez Niemcy, każe przypuszczać, że źródło to ówczesne władze umiejętnie wykorzystywały w umacnianiu polskich wpływów na tych terenach ${ }^{59}$.

Istotnym uzupełnieniem dawnych rozkładów jazdy są działy reklamowe. W wielu przypadkach rozrastały się one do sporych rozmiarów, objętością przewyższając zasadniczą część druku. Działy te zawierały ogłoszenia różnego pokroju. Znaczącą grupę tworzą inseraty o treści stricte turystycznej. Składają się nań ogłoszenia hoteli, pensjonatów, restauracji, biur podróży i przewodników, przewoźników, składów z towarami przydatnymi w podróży, instytucji odwiedzanych przez turystów. Działy reklamowe zawierały także ogłoszenia firm innych branż, na pozór obcych miłośnikom wojaży, np. firmy budowlane, zakłady usługowe. Tak zestawione fragmenty są dla historyków kopalnią wiedzy o życiu gospodarczym, społecznym i kulturalnym dawnych miast i miasteczek na ziemiach polskich do 1939 r. Język reklam, ich charakter może być także przydatny w badaniach nad metodami perswazji dawniej stosowanymi.

Przedstawione powyżej propozycje wykorzystania rozkładów jazdy w badaniach historycznych nie wyczerpują długiej listy możliwości. Zaprezentowane przykłady są w moim odczuciu szczególnie wartościowe i godne rozwinięcia. Historycy — zupełnie niesłusznie — nie dostrzegają zalet wynikających ze specyfiki samego źródła. Aktualność i precyzja to w moim odczuciu największe atuty kolejowych rozkładów jazdy. Jest to materiał, po który winni sięgnąć nie tylko badacze zajmujący się dawnymi podróżami, historią turystyki i oczywiście kolejnictwa (ci z racji swych zainteresowań rozkłady jazdy winni traktować, jako lekturę nieomal obowiązkową), ale także specjaliści od szeroko pojmowanych zagadnień gospodarczych i społecznych.

\section{Old Train Timetables and Their Usefulness in Historical Research}

Summary: The article devoted to other transport timetables, issued in the form of independent prints which were published on Polish territory in the $19^{\text {th }}$, century and first half of the $20^{\text {th }}$, century (until 1939). These are rare prints in Poland, even the biggest national libraries, including the specialist ones have modest and incomplete collections (an exception is the National Library in Warsaw, where the considerable collection of timetables from interwar period is situated). Originally, the timetables were issued irregularly, additionally each railway company conducted a separate information policy. Joint publishing ventures were rare. The turn of the $19^{\text {th }}$, and the $20^{\text {th }}$ century brought the significant change, mainly due to flag carriers who decided to more comprehensive and untypical printing initiatives. In addition to the items aimed at travellers, there were also timetables issued, envisaged for business use. The editions of timetables for particular stations or raliway nodes were rare until 1914. In the period of the Second Republic all known editorial solutions became more popular. New concepts of timetables also appeared. In general, after the World War I, quality and accessibility of the railway timetables on market improved. There were specially created institutions that took care of publishing timetables, some professional editors were also involved in it, for whom the production of timetables constituted the marginal of business and some casual publishers, who were performing other professions every day. Apart from the general characteristics of the source, which was done in the first part of the article, the determination of suitability of timetables in historical research was also done. It is certainly the valuable source material which should be taken by reserchers of different fields, involved not only in railway history.

\footnotetext{
${ }^{59}$ Szerzej o wykorzystaniu rozkładów do celów propagandowych zob. D. Opaliński, Kolejowe rozkłady jazdy, s. 330-334.
} 
Nota o autorze: D a r i u s z O p a li ń s k i, dr, adiunkt w Instytucie Historii Uniwersytetu Rzeszowskiego (Zakład Archiwistyki i Nauk Pomocniczych Historii). Zainteresowania badawcze: historia społeczna XIX w., historia turystyki, podróżowania i kolejnictwa, źródłoznawstwo XIX i XX w. Publikował artykuły m.in. w „Kwartalniku Historii Kultury Materialnej” i „Acta Poloniae Historica”. Autor monografii pt. „Przewodniki turystyczne na ziemiach polskich w okresie zaborów. Studium historyczno-źródłoznawcze” (Krosno 2012; wyd. 2: Krosno 2013). Author: Dariusz Opaliński, Ph.D., lecturer in the Institute of History at the University of Rzeszow, (the Department of Archive Studies and Auxiliary Sciences of History). The research interests are: social history of the19th century, history of tourism, travelling and railways, study of sources of the $19^{\text {th }} / 20^{\text {th }}$ century. The published articles among others are: „Kwartalnik Historii Kultury Materialnej”, „Acta Poloniae Historica” and the monograph entitled „Przewodniki turystyczne na ziemiach polskich w okresie zaborów. Studium historyczno-źródłoznawcze” (Krosno 2012; ed. 2: Krosno 2103).

Uniwersytet Rzeszowski, ul. Rejtana 16 C, 35-959 Rzeszów, Instytut Historii,

Zakład Archiwistyki i Nauk Pomocniczych Historii

e-mail: dopal1@wp.pl

\section{Bibliografia}

Opracowania i źródła

Bradshaw-Mitchell V., Bradshaw's History, Midhurst 2012

Bray M.I., Railway Tickets, Timetables \& Handbills, Ashbourne 1986

Bryja M., Polskie Towarzystwo Księgarń Kolejowych „Ruch”, „Z Badań Nad Polskimi Księgozbiorami Historycznymi", t. 19, 1999, s. 19-64

Dokładny rozkład jazdy kolei galicyjskich, Lwów 1876; Rozkład i ceny jazdy droga żelazna z Krakowa do Lwowa, Czerniowiec, Wrocławia, Poznania $i$ Wiednia. Przepisy pocztowe tudzież wykaz poczt osobowych w Galicji i opłaty od depesz telegraficznych, Kraków 1867

Dominas P., Powstanie i rozwój kolei na Ziemi Kłodzkiej w latach 1854-1914, Kłodzko 2009

Dziennik Urzędowy Ministerstwa Kolei

Dziennik Urzędowy Ministerstwa Kolei Żelaznych

Dziennik Urzędowy Ministerstwa Komunikacji

Esbester M.O., Designing time: the design and use of nineteenth-century transport timetables, „, Journal of Design History", Vol. 22, 2009, no 2, p. 91-113.

Keller D., Dyrekcja Okręgowa Kolei Państwowych w Katowicach w latach 1922-1939: geneza, podstawy prawne, organizacja i funkcjonowanie, Rybnik 2013

Kurier Kolejowy. Ważny od 1. maja 1914. Rozkład jazdy pociagów osobowych i pospiesznych w Galicji i Bukowinie. Połączenia do miast za granica, do miejsc kapielowych oraz ceny biletów do wszystkich stacji. Eisenbahn-Courier. Giltig vom 1. Mai 1914. Fahrplan der personen- und eilzüge für Galizien und Bukowina. Samt Verbindungen mit den Städten des Auslandes, der Curorte, und Fahrkartenpreise für alle Stationen, Lwów 1914

Lomazzi B.S., Railroad Timetables, Travel Brochures and Poster. A History and Guide for Collectors, Golden Hill 1995

Opaliński D., Dyszlem i pod para, czyli o galicyjskim kolejowo-pocztowym rozkładzie jazdy z 1867 r., „Kwartalnik Historii Kultury Materialnej”, 2014 nr 4, s. 613-624

Opaliński D., Kolejowe rozkłady jazdy w okresie II RP — funkcje społeczne źródła, w: Komunikowanie i komunikacja $w$ dwudziestoleciu międzywojennym, red. K. Stępnik i M. Rajewski, Lublin 2010, s. 325-335

Rozkład jazdy pociągów wszystkich państwowych dróg żelaznych bytej: Galicji, Królestwa Kongresowego, Księstwa Poznańskiego, Śląska Cieszyńskiego oraz kolejach podjazdowych z uwzględnieniem ostatnich zmian, R. 1, wyd. 6, październik 1919, Warszawa [1919]

Rozkład jazdy polskich Kolei państwowych „Pekape” z uwzględnieniem ostatnich zmian, R. 1, wyd. 1, [ważny od lipca 1921], Warszawa [1921]

Schenkera pierwszy polski kurier kolejowy na sezon letni 1893. Z 2 mapami kolejowymi. Ważny od 1. czerwca 1893, III, 1893, Lwów 1893

Tomasik W., To już jest koniec..., w: tenże, Pociąg do nowoczesności. Szkice kolejowe, Warszawa 2014, s. 275-280

Walter W.K., Rozkład jazdy pociagów pasażerskich na kolejach żelaznych w Królestwie Polskiem i przylegających. Sezon letni obowiazujacy od dnia 18 kwietnia (1 maja) 1911 r. Zebrat i wydat..., Warszawa 1911 